\title{
Changes in antibiotic sensitivity in strains of Staphylococcus aureus, 1952-78
}

\author{
ZEHRA A HASSAM, ELIZABETH J SHAW, R A SHOOTER, D B CARO
}

British Medical fournal, 1978, 2, 536-537

\section{Summary and conclusions}

Two hundred strains of Staphylococcus aureus isolated from outpatients with infections of the skin and subcutaneous tissues were tested for sensitivity to penicillin, erythromycin, tetracycline, sodium fusidate, methicillin, clindamycin, chloramphenicol, and gentamicin. One hundred and sixty-three $(81.5 \%)$ of the strains were resistant to penicillin and $16(8 \%)$ resistant to tetracycline. Incidence of resistance to other antibiotics was low. No strain was resistant to chloramphenicol, gentamicin, or methicillin.

When compared with results of earlier studies, there was an increase in the incidence of resistance to penicillin and tetracycline, but no appreciable increase in resistance to other antibiotics.

\section{Introduction}

Reports in $1952,1955,1957,1960$, and $1968^{1-5}$ on the sensitivity of strains of Staphylococcus aureus isolated from patients attending the casualty department of St Bartholomew's Hospital showed that the percentage of strains resistant to penicillin increased from $16^{\circ} \%$ to $50 \%$. We decided to determine the sensitivity pattern of Staph aureus to eight antibiotics in current use and to note any changes in the decade since the last report.

\section{Materials and methods}

Swabs were taken from patients with acute infections of the skin and subcutaneous tissues who attended the accident and emergency department between January and April 1978. Patients who had

\footnotetext{
Department of Medical Microbiology, St Bartholomew's Hospital, London EC1A 7BE

ZEHRA A HASSAM, MB, MRCPATH, senior registrar in bacteriology

ELIZABETH J SHAW, MD, MRCPATH, senior lecturer in medical microbiology

R A SHOOTER, MD, FRCPATH, professor of medical microbiology

Accident and Emergency Department, St Bartholomew's Hospital, London EC1A 7BE

D B CARO, FRCS, consultant
}

attended any hospital outpatient or inpatient department within the previous two months were excluded. We also noted whether patients had received antibiotic treatment during this period.

Swabs were cultured on blood agar plates and colonies resembling Staph sp were examined for coagulase production by the tube method. Isolates that produced coagulase were regarded as Staph aureus. These isolates were then investigated for antibiotic sensitivity by disc diffusion. ${ }^{6}$ The following antibiotics were tested on a lysed horseblood agar plate: penicillin (1 unit); erythromycin $(5 \mathrm{~kg})$; tetracycline $(10 \mu \mathrm{g})$; chloramphenicol $(10 \mu \mathrm{g})$; sodium fusidate (Fucidin) $(10 \mu \mathrm{g})$; clindamycin $(2 \mu \mathrm{g})$; and gentamicin $(10 \mu \mathrm{g})$. Methicillin sensitivity was determined using a 10- $\mu \mathrm{g}$ disc and the organism inoculated on to a $5 \%$ salt agar plate. The control organism was the Oxford strain of Staph aureus. Organisms were regarded as resistant to penicillin if the colonies at the edge of the zone were full-sized, giving a heaped-up edge, in contrast to organisms sensitive to the drug, where a smooth edge is produced by colonies of diminishing size. For the other antibiotics, organisms were termed sensitive when the zone radius was smaller than the zone with the control organism by $3 \mathrm{~mm}$ or less.

Minimum inhibitory concentrations (MICs) against erythromycin tetracycline, chloramphenicol, sodium fusidate, clindamycin, and gentamicin were determined by agar dilution using direct sensitivity test agar (Oxoid) with $5^{\circ}$ lysed blood. Salt agar was used to determine the MIC of methicillin. The penicillin MIC was not determined, since resistance to penicillin is due to production of penicillinase. Antibiotic powders were diluted in sterile water and incorporated in agar to give a final dilution of $0 \cdot 06-64 \mathrm{mg} / \mathrm{l}$. Plates were inoculated with a multiple-point inoculator, delivering $10^{3}$ organisms $/ \mathrm{ml}$. All results were read after incubation at $37^{\circ} \mathrm{C}$ for 18 hours, and the MIC was taken as the lowest concentration of drug showing no growth.

\section{Results}

Table I shows the antibiotic sensitivity pattern of the 200 strain of Staph aureus. One hundred and sixty-three $(81.5 \%)$ of them were resistant to penicillin. None of the strains were resistant to chloramphenicol, gentamicin, or methicillin. Twenty-six strains $(13 \%)$ were resistant to two or more antibiotics, and these are shown in table II. Sixteen of the 200 patients had received an antibiotic in the previous two months. The resistance pattern of isolates from these patients is shown in table III.

TABLE II-Antibiotic resistance patterns of 200 strains of Staph aureus

\begin{tabular}{c|c|c|c|c|c|c|c}
\hline $\begin{array}{c}\text { Resistance } \\
\text { pattern }\end{array}$ & FS & P & P T & P F & P E & P E T C & Total \\
\hline No of strains & 37 & 137 & 15 & 7 & 3 & 1 & 200 \\
\hline
\end{tabular}

FS = Fully sensitive. $P=$ Penicillin. $T=$ Tetracycline. $E=$ Erythromycin. $F=$ Sodium fusidate. $\mathbf{C}=$ Clindamycin.

TABLE I-Sensitivity of 200 strains of Staph aureus to eight antibiotics

\begin{tabular}{|c|c|c|c|c|c|c|c|c|c|c|c|c|c|c|c|}
\hline \multirow{2}{*}{\multicolumn{4}{|c|}{ Antibiotic }} & \multirow{2}{*}{$\begin{array}{l}\text { No }(\%) \text { strains } \\
\text { resistant by } \\
\text { disc diffusion }\end{array}$} & \multicolumn{11}{|c|}{ Minimum inhibitory concentration (mg/l) } \\
\hline & & & & & 0.06 & 0.12 & 0.25 & 0.5 & 1 & 2 & 4 & 8 & 16 & 32 & 64 \\
\hline $\begin{array}{l}\text { Penicillin* } \\
\text { Erythromycin } \\
\text { Tetracycline } \\
\text { Chloramphenicoi } \\
\text { Methicillin } \\
\text { Sodium fusidate. } \\
\text { Clindamycin } \\
\text { Gentamicin }\end{array}$ & $\begin{array}{l}. \\
\because \\
\because \\
\because \\
\because \\
.\end{array}$ & $\begin{array}{l}. \\
\because \\
\because \\
\ddot{0} \\
\because \\
.\end{array}$ & $\begin{array}{l}. \\
\because \\
\because \\
\because \\
\because \\
.\end{array}$ & $\begin{array}{c}163(81 \cdot 5) \\
4(2) \\
16(8) \\
0 \\
0 \\
7(3.5) \\
1(0.5) \\
0\end{array}$ & 1 & $\begin{array}{r}27 \\
199 \\
42\end{array}$ & $\begin{array}{l}122 \\
139\end{array}$ & $\begin{array}{r}85 \\
2 \\
44 \\
18\end{array}$ & $\begin{array}{r}98 \\
111\end{array}$ & $\begin{array}{r}1 \\
3 \\
72\end{array}$ & $\begin{array}{r}1 \\
194 \\
15\end{array}$ & $\begin{array}{l}1 \\
3 \\
2\end{array}$ & 3 & 1 & $\begin{array}{l}1 \\
7\end{array}$ \\
\hline
\end{tabular}

*Minimum inhibitory concentration of penicillin was not tested. 
TABLE III-Antibiotic resistance pattern of strains of Staph aureus isolated from patients who had received an antibiotic. Number of patients in parentheses

\begin{tabular}{|c|c|c|c|c|}
\hline \multicolumn{3}{|c|}{ Antibiotic } & No of patients & Resistance patterns* \\
\hline $\begin{array}{l}\text { Penicillin ..: } \\
\text { Erythromycin } \\
\text { Tetracycline }\end{array}$ & $\begin{array}{l}. . \\
\cdots\end{array}$ & $\begin{array}{l}. . \\
\cdots\end{array}$ & $\begin{array}{r}10 \\
5 \\
1\end{array}$ & $\begin{array}{l}\text { P (9); P T (1) } \\
\text { F } \\
\text { P T (1); P (3); P E (1) }\end{array}$ \\
\hline
\end{tabular}

*See footnote to table II for abbreviations.

\section{Discussion}

Previous reports from this casualty department showed that the percentage of strains of Staph aureus resistant to penicillin had gradually increased from $6 \%$ to $50 \% .^{1-5}$ This study shows that the trend has continued, $81.5 \%$ of strains now being resistant to penicillin. This result approximates to the incidence of penicillin resistance found in strains isolated from inpatients. ${ }^{78}$ None of the 200 strains of Staph aureus were resistant to methicillin, chloramphenicol, or gentamicin. Chloramphenicol resistance has not increased since the surveys in 1952 and $1955 .^{12}$ Resistance to tetracycline has increased, however, results of reports in 1955 showing no resistant strains, while in $19686.5 \%$ of strains were resistant. ${ }^{5}$ The present series shows a slight increase to $8 \%$. Only a few strains were resistant to erythromycin, clindamycin, and sodium fusidate. Most of the strains were resistant only to one antibiotic, $12.5 \%$ were resistant to two drugs, and only one strain was resistant to more than three antibiotics.

Patients infected with strains resistant only to penicillin still respond to treatment with this drug, ${ }^{5}$ possibly because such strains produce only a small amount of penicillinase. ${ }^{9}$ Our findings therefore suggest that penicillin is still suitable antibiotic treatment in outpatients, and erythromycin is a suitable alternative for those allergic to penicillin.

\section{References}

${ }^{1}$ Birnstingl, M A, Shooter, R A, and Hunt, M F, British Medical fournal, $1952,2,253$.

${ }^{2}$ Rees, E G, Shooter, R A, and Shawe, G D, British Medical fournal, 1955, 1, 1409 .

${ }^{3}$ Burn, J I, et al, British Medical fournal, 1957, 2, 193.

4 MacFarlane, D A, et al, British Medical fournal, 1960, 2, 900.

5 Price, D J E, et al,, British Medical fournal, 1968, 3, 407.

6 Stokes, J E, Clinical Bacteriology, 4th edn. London, Edward Arnold, 1975.

Thompson, R E, Harding, J W, and Simon, R D, British Medical fournal, $1960,2,708$.

${ }^{8}$ Ross, S, et al, fournal of the American Medical Association, 1974, 229, 1075.

${ }^{9}$ Richmond, M H, et al, Lancet, 1964, 1, 293.

(Accepted 16 fune 1978)

\section{Chronic bronchitis: is bacteriological examination of sputum necessary?}

This study was undertaken to assess whether the common hospital practice of routine bacteriological examination of specimens of purulent sputum is necessary for the efficient management of infective exacerbations of chronic bronchitis.

\section{Patients, methods, and results}

Sixty patients admitted to hospital with exacerbations of chronic bronchitis associated with purulent sputum were included and randomly allocated into two groups. Group A was managed in the usual way, with regular reviews of the bacteriological reports of sputum culture. Group B had sputum examined, but the reports were not returned to the supervising physician unless formally requested. There were 30 patients in each group. The average ages were similar (group A: $64 \cdot 2$ years; group B: $67 \cdot 1$ years). Eleven patients in group $A$ and 12 patients in group $B$ had ventilatory failure on admission. Inflammatory changes were present on an initial chest $x$-ray film of 11 patients in each group. The approximate time of sputum purulence before admission for both groups was 11 days, and 10 patients in group $\mathbf{A}$ compared with 12 in group $B$ had had previous antibiotic treatment. Treatment with antibacterial drugs was selected according to usual practice and sputum was examined bacteriologically immediately after admission and after five or seven days' treatment. Sputum appearance was noted daily. Chest $x$-ray films were taken at appropriate intervals, and treatment changes were documented.

In group $A$ the sputum of 25 patients became mucoid in 7.08 days (range 1-16). The sputum of the other five patients remained purulent. One of these patients had bronchiectasis. In group B 28 patients produced mucoid sputum in 6.08 days (range $2-12$ ). One of the two patients with persistently purulent sputum had bronchiectasis and the other died from a cerebrovascular accident while his sputum was still purulent. The table shows that the results of sputum culture were similar in the two groups. Details of chemotherapy given to both groups are shown in the table. Twenty-four patients in group A, compared with 26 in group B, required a single course of antibiotic. In six cases from group $A$ a change of treatment was necessary but in only two was mucoid sputum achieved. In group B antibiotic treatment was changed in four cases and in only one patient was there failure of conversion of sputum. In group $A$ one change of treatment was made because of bacteriological findings but this patient's sputum remained purulent. In group B it was felt necessary to examine bacteriological results in three patients because of poor clinical response, but in none of these did the bacteriology findings affect the outcome. The average times to the clearing of
Details of chemotherapy given to both groups and the numbers of patients with successful or unsuccessful conversion of sputum from purulent to mucoid. Also shown are the results of sputum culture initially and after 5-7 days

\begin{tabular}{|c|c|c|c|c|}
\hline & \multicolumn{4}{|c|}{ Number of patients } \\
\hline & Gr & oup A & Grc & oup B \\
\hline \multirow{2}{*}{ Treatment } & Sputum & conversion & Sputum & conversion \\
\hline & Successful & Unsuccessful & Successful & Unsuccessful \\
\hline 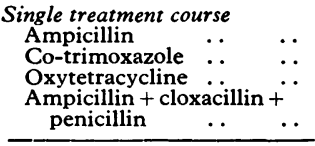 & $\begin{array}{r}15 \\
4 \\
0 \\
4 \\
\end{array}$ & $\begin{array}{l}1 \\
0 \\
0 \\
0 \\
\end{array}$ & $\begin{array}{r}17 \\
5 \\
2 \\
1 \\
\end{array}$ & $\begin{array}{l}1 \\
0 \\
0 \\
0 \\
\end{array}$ \\
\hline Total $\ldots$ & 23 & 1 & 25 & 1 \\
\hline $\begin{array}{l}\text { Multiple treatment course } \\
\text { Co-trimoxazole/ampicillin } \\
\text { Ampicillin/gentamicin } \\
\text { Co-trimoxazole/gentamicin } \\
\begin{array}{c}\text { Chloramphenicol/ } \\
\text { gentamicin } \quad . . \quad . .\end{array} \\
\end{array}$ & $\begin{array}{l}2 \\
0 \\
0 \\
0 \\
\end{array}$ & $\begin{array}{l}2 \\
1 \\
1 \\
0 \\
\end{array}$ & $\begin{array}{l}2 \\
0 \\
0 \\
1 \\
\end{array}$ & $\begin{array}{l}0 \\
1 \\
0 \\
0 \\
\end{array}$ \\
\hline Total .. & 2 & 4 & 3 & 1 \\
\hline Organisms isolated & \multicolumn{2}{|c|}{ On admission: day $5-7$} & \multicolumn{2}{|c|}{ On admission: day 5-7 } \\
\hline 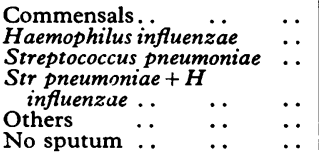 & $\begin{array}{r}16 \\
8 \\
3 \\
0 \\
3 \\
0\end{array}$ & $\begin{array}{r}22 \\
1 \\
0 \\
0 \\
3 \\
4\end{array}$ & $\begin{array}{r}15 \\
10 \\
2 \\
1 \\
2 \\
0\end{array}$ & $\begin{array}{r}23 \\
2 \\
0 \\
0 \\
2 \\
3\end{array}$ \\
\hline
\end{tabular}

the inflammatory changes in the chest $x$-ray film in both groups were similar (group A : 8.5 days; group B: 7.5 days).

\section{Comment}

After completion of the trial a review of results in group B indicated that no changes of treatment would have been made had the bacteriological results been immediately available. Indeed, these reports might have been misleading in three patients since there was satisfactory sputum clearance with antibiotics to which in-vitro resistance had been reported. 